\title{
Protestantism and Human Capital in Guatemala and the Republic of Korea
}

\section{Citation}

McCleary, Rachel M. 2013. Protestantism and Human Capital in Guatemala and the Republic of Korea. Asian Development Bank Economics Working Paper Series, No. 332. 2013

\section{Permanent link}

http://nrs.harvard.edu/urn-3:HUL.InstRepos:10579211

\section{Terms of Use}

This article was downloaded from Harvard University's DASH repository, and is made available under the terms and conditions applicable to Other Posted Material, as set forth at http:// nrs.harvard.edu/urn-3:HUL.InstRepos:dash.current.terms-of-use\#LAA

\section{Share Your Story}

The Harvard community has made this article openly available.

Please share how this access benefits you. Submit a story.

\section{Accessibility}




\section{ADB Economics Working Paper Series}

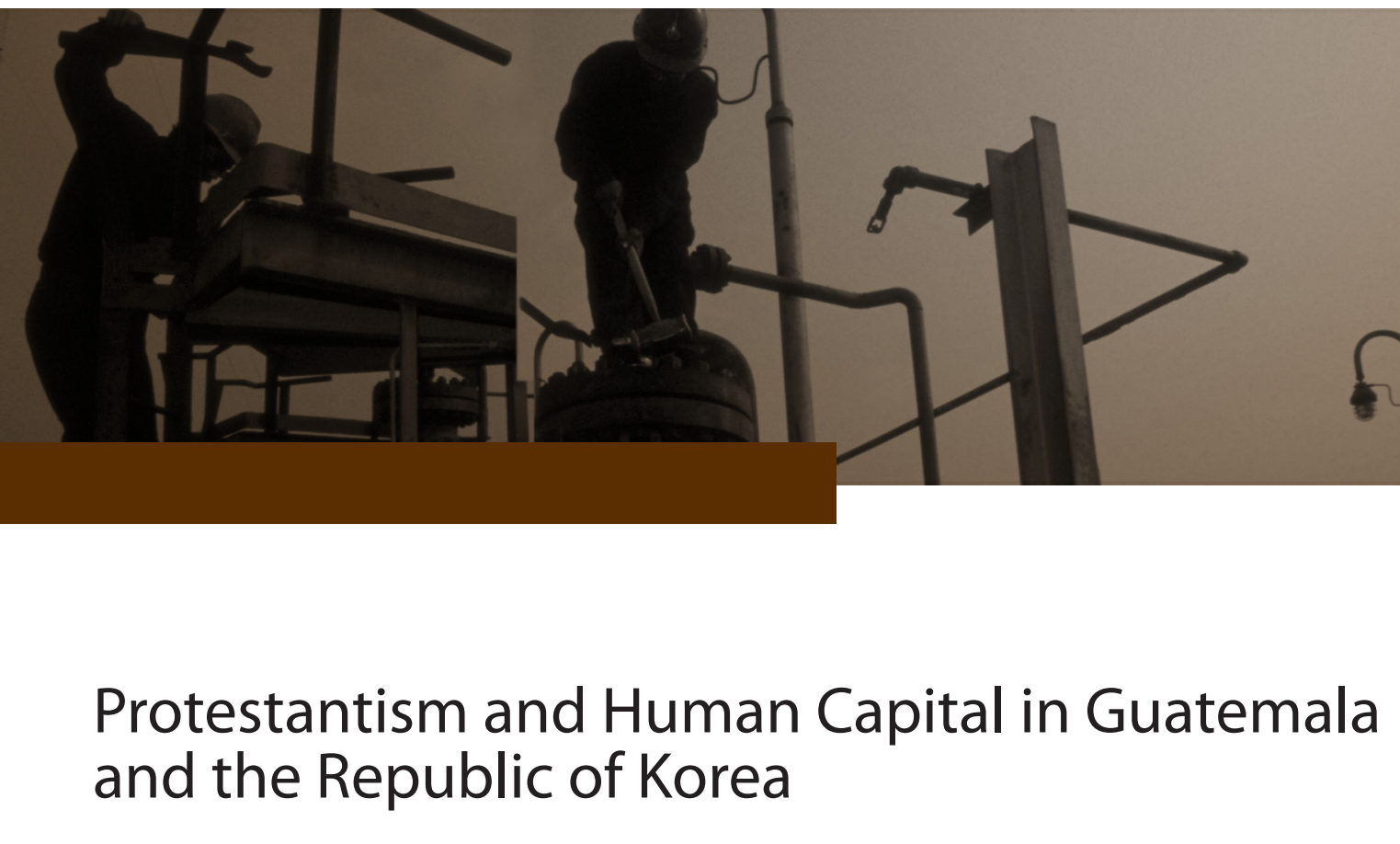

Rachel M. McCleary

No. 332 | January 2013

Asian Development Bank 
ADB Economics Working Paper Series

\section{Protestantism and Human Capital in Guatemala and the Republic of Korea}

Rachel M. McCleary

No. 332 January 2013
Rachel M. McCleary is a Senior Research Fellow at Taubman Center, Kennedy School of Government, Harvard University.

I would like to express my appreciation to the participants in the Asian Development Bank project on Human Capital and Economic Development 2011 and to Rick McArthur and Steve Elliott my thanks for our discussions on the topic of literacy and Protestantism. David Hall provided helpful comments on the paper for which I am grateful. I would like to thank Junhyun Kim, Jonatan Lemus Avila, and Jeff Howry for their research assistance.

\section{Asian Development Bank}


Asian Development Bank

6 ADB Avenue, Mandaluyong City

1550 Metro Manila, Philippines

www.adb.org

(C) 2013 by Asian Development Bank

January 2013

ISSN 1655-5252

Publication Stock No. WPS135359

The views expressed in this paper are those of the author and do not necessarily reflect the views and policies of the Asian Development Bank (ADB) or its Board of Governors or the governments they represent.

ADB does not guarantee the accuracy of the data included in this publication and accepts no responsibility for any consequence of their use.

By making any designation of or reference to a particular territory or geographic area, or by using the term "country" in this document, ADB does not intend to make any judgments as to the legal or other status of any territory or area.

Note: In this publication, "\$" refers to US dollars.

The ADB Economics Working Paper Series is a forum for stimulating discussion and eliciting feedback on ongoing and recently completed research and policy studies undertaken by the Asian Development Bank (ADB) staff, consultants, or resource persons. The series deals with key economic and development problems, particularly those facing the Asia and Pacific region; as well as conceptual, analytical, or methodological issues relating to project/program economic analysis, and statistical data and measurement. The series aims to enhance the knowledge on Asia's development and policy challenges; strengthen analytical rigor and quality of ADB's country partnership strategies, and its subregional and country operations; and improve the quality and availability of statistical data and development indicators for monitoring development effectiveness.

The ADB Economics Working Paper Series is a quick-disseminating, informal publication whose titles could subsequently be revised for publication as articles in professional journals or chapters in books. The series is maintained by the Economics and Research Department.

Printed on recycled paper 


\section{CONTENTS}

ABSTRACT V v v v v v v

$\begin{array}{ll}\text { I. INTRODUCTION } & 1\end{array}$

II. 19TH CENTURY PROTESTANTISM AND US FOREIGN MISSIONS 2

III. THE FUNDAMENTALIST NATURE OF THE GUATEMALA RELIGION MARKET 5

IV. THE TRIUMPH OF THE SOCIAL GOSPEL IN THE REPUBLIC OF KOREA 13

V. CONCLUSIONS 18

$\begin{array}{ll}\text { REFERENCES } & 20\end{array}$ 



\begin{abstract}
Protestant missions from the United States entered the Republic of Korea and Guatemala at the same time (1884 and 1882, respectively). Yet, their impact on human capital has been divergent. The analysis presented in this paper supports the findings of Woodberry $(2004,2009,2011)$ and Nunn $(2009)$ in the case of the Republic of Korea. Mainline Protestant missions-Presbyterian and Methodistpromoted the Social Gospel and were the largest in the Republic of Korea implementing successful strategies such as using Korean (Hangul) as the lingua franca in their schools, churches, and medical facilities. Whereas the mainline Protestant denominations in the Republic of Korea successfully promoted investment in human capital, the case of Guatemala does not follow this pattern. Evangelical, Pentecostal, and neo-Pentecostal denominations and churches focused their efforts on evangelizing. Their premilliennialist beliefs translated into an eschatological urgency of conversion with little investment in human capital. As a result, institution-building requisite for investment in human capital (establishing educational institutions and medical facilities) characterized Protestant missions in the Republic of Korea, but not Guatemala. These diverging approaches to exporting Christianity have had differing longterm effects on the two societies.
\end{abstract}

Keywords: human capital, literacy, institutions, religion, history

JEL Classification: J24, N35, N36, O43 



\section{INTRODUCTION}

The first United States (US) missions to Guatemala and the Republic of Korea represent different types of Protestantism that emerged at the end of the 19th century. Mainline Protestantism and fundamentalism were on dichotomous trajectories. ${ }^{1}$ Whereas mainline Protestant denominations were advocating what was termed the Social Gospel or Social Creed, the fundamentalist movements were focusing on individual spirituality. Robert Woodberry's cross-country analysis (Woodberry and Shah 2004; Woodberry 2009, 2011) on Protestant missions shows a positive effect of Protestantism on education and democratic institutions. Nathan Nunn (2009) finds that Protestants were successful in converting Africans to their brand of Christianity within the context of offering medical services and educational opportunities. Nunn and Woodberry agree that Protestant missions as a single type when compared to Roman Catholic missions had stronger effects on conversion and increased educational attainment. This broad-stroked analysis overlooks the rise of the Holiness movements at the end of the nineteenth century and Pentecostals in the early twentieth century. ${ }^{2}$ These fundamentalist movements immediately engaged in evangelizing overseas and continue to be the largest growing religion in the world by conversion. These groups continue to send out more missionaries than any other Protestant type (Table 1).

Table 1: North American Protestant Missionary Personnel

(of which about $10 \%$ are Canadian)

\begin{tabular}{lrrrrrrrr}
\hline Sponsor & $\mathbf{1 8 9 0}$ & $\mathbf{1 9 1 5}$ & $\mathbf{1 9 2 5}$ & $\mathbf{1 9 5 2}$ & $\mathbf{1 9 6 0}$ & $\mathbf{1 9 7 0}$ & $\mathbf{1 9 7 3}$ & $\mathbf{1 9 7 6}$ \\
\hline Denominations belonging to NCCC $^{\mathrm{a}}$ & 934 & 9,072 & 11,020 & 7,937 & 8,213 & 6,199 & 4,013 & 3,105 \\
NCCC affiliated but not belonging $^{\mathrm{N}}$ & & & & 2,439 & 2,111 & 3,258 & 2,908 & 2,234 \\
All others $^{\mathrm{C}}$ & & & 2,588 & 8,160 & 19,056 & 25,003 & 28,149 & 30,119 \\
Total & 934 & 9,072 & 13,608 & 18,536 & 29,380 & 34,460 & 35,070 & 35,458 \\
\hline
\end{tabular}

a The National Council (earlier, the Federal Council) did not form until 1908 and, hence, the first figure in this row is technically mislabeled.

b The largest of these sponsors are Seventh Day Adventist, Missouri Synod Lutheran, and American Lutheran Church.

c The largest of these sponsors are Southern Baptist and Wycliffe Bible Translators.

Source: W. Richie Hogg, "The Role of Americal Protestantism in World Mission" in R. P. Beaver (ed.), American Missions in Bicentennial Perspective. Adapted from Tables III and VI.

Phillip E. Hammond (1983). "In Search of a Protestant Twentieth Century: American Religion and Power since 1900." Review of Religious Research, 24, 4, Voluntary Action and Religion: A Symposium (June): 281-294.

The analysis presented in this paper supports the findings of Woodberry and Nunn in the case of the Republic of Korea. The mainline Protestant missions-Presbyterian and Methodist-that promoted the Social Gospel were the largest in the Republic of Korea and implemented successful strategies such as using Korean ("Hangul") as the lingua franca in their work. The case of Guatemala does not follow this pattern. The Presbyterian Church-US mission was unable to successfully compete with Evangelical and Pentecostal missionaries. The Evangelical and Pentecostal missionaries (premillennialists) were focused on the urgency of conversion with little investment in human capital. As a result, institution-building requisite for

1 Fundamentalism refers to Christians who believe in the inerrancy of the Bible, personal conversion to Christ as savior, dispensational theology (namely, God is unfolding a purpose for the world), premillennial eschatology, and institutional separation from mainline Protestant denominations (Marsden 1987, 15: 190-197; Steigenga 2001: 89). Holiness and Pentecostal movements, churches, and denominations are considered to be fundamentalist.

2 Woodberry, in his work, refers to all Protestant missions as "Conversionary Protestants." To assume that all Protestant missions during the 19th Century up to 1923 (where his research ends) were promoting mass education, healthcare, human rights is inaccurate making his findings weak. 
investment in human capital characterized Protestant missions in the Republic of Korea but not Guatemala. These diverging approaches to exporting Christianity continue to have different effects on the two societies.

\section{19TH CENTURY PROTESTANTISM AND US FOREIGN MISSIONS}

Two trends-ecumenicalism and fundamentalism-in the US during the 19th century characterized early Protestant missions to Guatemala. ${ }^{3}$ The evangelical movement of the early 19th century, otherwise known as the First Great Awakening (1730-1760), emphasized Christian living through the reading of religious literature. The American Bible Society (1816) and the America Tract Society (1825) when formed had the expectation that as organizations they would be distributing Bibles and tracts in the newly independent countries of Spanish America. ${ }^{4}$ The First Great Awakening (1730-1760) and the Third Great Awakening (late 1850searly 1900s) of which the Holiness groups and Pentecostals to be discussed here belonged to, emphasized prayer, Bible reading, and the intercession of the Holy Spirit in personal spiritual revival (sanctification). These two Awakenings produced schisms and new sects but those formed in later part of the 1800s were ecumenical in nature. The ecumenical aspect of the Third Awakening came from the Second Great Awakening (1800-1840s) which stressed Christian unity and the global spread of Christianity. During this period, Christian missionary movements (for example, the Student Volunteer Movement for Foreign Missions begun in 1866) were formed having a lasting effect on Protestant missions worldwide be they denominational, independent, or interdenominational.

Both the Student Volunteer Movement and later the Victorious Life Testimony (1912) attracted the college-educated into foreign mission work. These movements were ecumenical, that is interdenominational, in nature and assisted young missionaries in finding financial backing until they joined a denominational mission board or an independent faith mission. Belief in the "four-fold" gospel of personal salvation through sanctification, known as baptism by the Holy Spirit, divine healing, and millennial beliefs motivated international missionary work in India, Asia, Latin America, and Africa. In addition to Holiness groups and churches, agencies such as the Pioneer Mission Agency were established solely for the purpose of financing missions and missionaries. Through the work of the founders of the Pioneer Mission Agency, a network of "prayer warriors" was developed with the sole purpose of praying for and funding indigenous lay workers (Dahlquist 1995: 66-71).

The independent faith missions at the end of the 1800s and into the next century were strengthened by denominational intransigence. Holiness groups formed in the early 1800s functioning as pressure groups on mainline Protestant denominations. ${ }^{5}$ These groups were formed outside denominational structures by members of Protestant denominations who

3 For a discussion of the evolution of Holiness movements into Pentecostalism and missions, see Case 2006. The term "ecumenicalism" is used interchangeably with "interdenominational." Fundamentalism refers to Christians who believe in the inerrancy of the Bible, personal conversion to Christ as savior, dispensational theology (namely, God is unfolding a purpose for the world), premillennial eschatology, and institutional separation from mainline Protestant denominations (Marsden 1987, 15: 190197; Steigenga 2001: 89). Holiness and Pentecostal movements, churches, and denominations are considered to be fundamentalist.

4 In 1819, the American Bible Society printed its first Spanish edition of the New Testament (American Bible Society 1819: 12). In 1823, a momentous year for the independence of Central America from Mexico, the American Bible Society began printing Bibles in Spanish and in 1826 began distribution of Bibles in Mexico (American Bible Society 1823: 8, 267).

5 These denominations would be primarily Methodist and Baptist and secondarily the Friends, Presbyterians, and Mennonites. 
retained formal affiliation with the established churches. ${ }^{6}$ The objective of the independent Holiness bodies was to reform denominations theologically and morally from within. Holiness groups were interdenominational in nature intended for prayer, fellowship, and mutual support of like-minded Christians but not as replacements for the denominational churches.

Beginning in the late 1800s, Holiness groups either voluntarily split or were expelled from their churches abandoning any expectation that existing denominations would reform. ${ }^{7}$ Having left their denominations, many Holiness leaders (both lay and ordained) became itinerate preachers. They traveled across the US worshipping in homes, on street corners, and camp grounds rather than in church buildings. ${ }^{8}$ They attracted individuals who had no denominational affiliation and who came to consider the Holiness group their main church. Characteristic of the Holiness movement was a national network of relationships among the leaders as they traveled across the US preaching. Leaders of Holiness groups and denominations joined to create nondenominational agencies to promote and fund missions both domestically and abroad. The structural characteristics of the Holiness groups-spontaneous worship services in informal settings by self-designated preachers-would make their faith easily adaptable to foreign missions.

As a result of denominational rejection, Holiness groups restructured themselves into independent churches such as the Church of God-Anderson, IN (1881) and interdenominational evangelizing societies such as the Christian and Missionary Alliance (1887) and the Pentecostal Alliance (1898). The interdenominational alliances were intended to complement, not compete with existing denominations. All the early missionaries to Guatemala were spiritually informed by the Holiness movements and guided by the ecumenical movements including those missionaries of mainline Protestant denominations. ${ }^{9}$

The intricate intertwining of relationships among individuals and organizations provided the human resources, spiritual goals, and financial means for global Protestant missions in the

6 The interdenominational nature of these Holiness groups distinguished them from those of the First Great Awakening (1730-1760).

7 Among these were the Church of God (Anderson, Indiana, est.1880), Church of God (Holiness, est. 1883), United Holy Church of America (est. 1886), Christian Missionary Alliance (est. 1883), Fire-Baptized Holiness Church (est. 1895), The Church of God in Christ (est. 1897), The Pentecostal Holiness Church (est. 1898), and the Pentecostal Mission (est. 1901).

8 A good example of this is James Octavias McClurkan, an ordained Presbyterian minister, who voluntarily left his assigned Presbyterian Church in San Jose, California, to become an independent preacher in Nashville, Tennessee. His trip from California to Tennessee turned into an evangelistic tour lasting two years (Strickland and Dunning: 1998:15). McClurkan founded an interdenominational organization called the Pentecostal Alliance (Strickland and Dunning: 1989), which complemented in the region of middle Tennessee the work of denominations such as the Methodists and Presbyterians (Strickland and Dunning 1998: 20-1). In 1901, McClurkan with a 25-member general committee renamed the Pentecostal Alliance the Pentecostal Mission (Strickland and Dunning 1998: 24). The Pentecostal Mission continued to be an interdenominational mission. In 1901, Reverend J.T. Butler and his wife, Emma Goodwin Butler, became the first Pentecostal Mission missionaries to Guatemala (Strickland and Dunning 1998: 26). In 1915, facing internal schism, the Pentecostal Mission merged with the Nazarene Church.

9 John Clark Hill was the first missionary for the Board of Foreign Missions of the Presbyterian Church (USA). Hill represented the one mainline Protestant denomination mission to officially enter Guatemala. He preached the inerrancy of the Bible and dispensational premillennialism (Bogenschild 1992: 51-2). The ecumenical nature of evangelicalism in the U.S. at the time not only downplayed the differences among the Protestant denominations but encouraged switching. Mutual assistance and cooperation among Protestant missionaries in Guatemala through the 1930s was understood as part of their Christian purpose. US Protestant ecumenism in Guatemala as well as other countries in Spanish Central and South America was informed by an accepted worldview that Spanish America required a Protestant reformation that would not only bring spiritual enlightenment (through the reading of the Bible) but civil liberties (the removal of Papal and Spanish tyranny). For a lively discussion of this worldview see Gribbin (1975). 
first half of the 20th century. ${ }^{10}$ What Holiness churches and the ecumenical movements shared was the evangelizing goal of converting the world to Christianity (Rouse and Neill 1968: 324345). Missionaries, with ties to interdenominational agencies such as the Student Volunteer Movement, the Victorious Life Testimony, the Pioneer Mission Agency, the American Bible Society, the American Tract Society, the Young Men's and Women's Christian Associations, and the Sunday School Times arrived in Guatemala as members of the Presbyterian Church US (1882), the interdenominational Central American Mission (CAM entered 1896), The Nazarene Church (1901), the California Friends Yearly Meeting (1902), Primitive Methodist (entered 1921). ${ }^{11}$

The second trend-fundamentalism-came at the beginning of the twentieth century with the formation of Pentecostalism, an outgrowth of the Holiness movement. ${ }^{12}$ The theological difference between Holiness groups and Pentecostals was the belief that speaking in tongues (glossolalia) always accompanied Holy Ghost baptism. Holiness and Pentecostal churches were diverse and independent. ${ }^{13}$ Holiness and Pentecostal churches of importance to the Guatemalan religion market are the Plymouth Brethren (entered 1900), ${ }^{14}$ Pentecostal Mission of Nashville (entered 1901), ${ }^{15}$ The Pentecostal League (1901), Pentecostal Holiness Church (entered 1903), ${ }^{16}$ Southern Pentecostal Union (entered 1910), the Assemblies of God (entered

10 An excellent example of the interconnected nature of the organizations and movements is the history of the formation of the Wycliffe Bible Translators. Its founder, William Cameron Townsend, was raised a Presbyterian and attended Occidental College (Presbyterian). As a student he joined the Student Volunteer Movement and after college became a colporteur in Guatemala for the nondenominational Bible House of Los Angeles. Townsend then became a missionary for the CAM. While a CAM missionary, the American Bible Society published Townsend's translation of the New Testament into Cakchiquel. When Townsend left the CAM to set up the Wycliffe Bible Translators, he did so with financial backing from the Pioneer Mission Agency and the Columbia Bible College in South Carolina (Svelmoe 2008).

11 The Primitive Methodist and Nazarene missions entered Guatemala by building on the work of existing Pentecostal missionaries. As a result, their official entry date is often that of the Pentecostal missionaries not the official denominational entry date. To this point, the Nazarene Church was formed in the US in 1915 yet its official entry date in Guatemala is given as 1901.

12 What has recently been the accepted history of Pentecostalism is that it became recognized as a distinct movement after the 1906 Azusa Street revival. Scholars have challenged this historical perspective contending that Pentecostal revivals were occurring prior to the Azusa Street revival and many at the same time as the Azusa Street revival.

13 The Primitive Methodist Church established its foreign mission board in 1905. The Plymouth Brethren established their agency Christian Missions in Many Lands in 1921. The Church of God founded their mission board in 1926, the Assemblies of God World Missions (AGWM) was founded in 1914, and the Pentecostal Church of the Nazarene, which in 1915, formed as a result of a series of mergers, became in 1919 the Church of the Nazarene, and had missions since 1898.

14 The Plymouth Brethren Church is an Evangelical denomination. Dr. Carlos Secord, an independent medical missionary of Plymouth Brethren affiliation, established his medical work in the department of El Quiché (Hays 1972: 15).

15 Reverend J.T. Butler, his wife, and Emma Goodwin Butler were the first Pentecostal Mission missionaries (Hudson 1976: 21). They first went to El Rancho in the department of El Progreso, and then moved on to the town of Zacapa the capital of the department by the same name. Also, see footnote 8.

16 Conway G. Anderson and Miss Willie Barnett, missionaries of the Tabernacle Church of Greenville, South Carolina, settled in Zacapa. In 1904, Conway's nephew, Richard Anderson, and his wife, Annie Maude, became Tabernacle missionaries to Guatemala. In 1906, Effie Mae Glover, a student of the Altamont Bible and Missionary Institute, Greenville, South Carolina (today the Holmes Bible College), began mission work in Guatemala with Reverend J.T. Butler and his wife (see footnote 8). In 1908, Amos Bradley arrived in Guatemala as an independent Pentecostal missionary supported by Mrs. Frank Nabors of Birmingham, Alabama (Canavesio 2005: 2). In 1909, Effie and Amos Bradley were married in Zacapa. They continued working as independent Pentecostal missionaries in San Jerónimo, Baja Verapaz. In 1912, the Bradley's joined the Holiness Pentecostal Church and in 1913 went to El Salvador. When Conway Anderson left the Guatemalan mission field in 1916, Amos and Effie Bradley returned to Guatemala supported by the North Carolina Holiness Pentecostal Church (Canavesio 2005: 1-3). Because of the tropical weather in Zacapa, they lived in Guatemala City and commuted by train to Zacapa, 
1914), the Church of the Nazarene (entered 1915), United Free Gospel and Missionary Society (entered 1916), ${ }^{17}$ National Association of Baptist Churches (1926), ${ }^{18}$ Church of God-Cleveland, TN (entered 1934), ${ }^{19}$ Assemblies of God (entered 1936), Church of God-Anderson, IN (entered 1947), International Church of the Foursquare Gospel (1956), Churches of Christ (1959), and several more. A third type of Protestant missionary came from those churches that formed while Holiness and Pentecostal movements were dominating the US religion market. The Seventh Day Adventists (entered 1908), Jehovah's Witnesses (entered 1927), and Mormons (entered 1947 ) retained distinct theological and doctrinal stances.

\section{THE FUNDAMENTALIST NATURE OF THE GUATEMALA RELIGION MARKET}

The first US missions to Guatemala represented three types of Protestantism at the end of the 19th century-mainline Protestant, Evangelical, Holiness-and at the beginning of the 20th century, Pentecostal clustered at one end of the religious spectrum with Evangelical and Holiness groups. By the early 1950s, the Holiness churches had moderated their stance on sanctification sufficiently to identify as Evangelical. (From here on in the discussion, I subsume Holiness groups under Evangelical). One of the main distinctions between mainline and the other groups was the focus of the later on evangelizing and to varying degrees the rejection of "civilizing" mission work in the form of education and institution-building (Svelmoe 2008: 67).

Whereas missionaries for the mainline and evangelical missions tended to have a college education, the Holiness and Pentecostal missionaries had mission and Bible institute training. The focus on evangelizing coupled with the premillennial urgency meant that mission work could not wait for missionaries to receive a college and seminary education. Mission institutes, such as Nyack Missionary Training Institute (founded in 1882), were established to train young people to use the Bible as their resource in evangelistic methods and outreach

their appointed mission area. In 1922, the Bradleys became Primitive Methodist missionaries in the department of Totonicapán, residing in San Cristóbal (Hays 1971: 16; Canavesio 2005: 6). Thus ended the presence of the Pentecostal Holiness Church mission work in Guatemala until 1991 when it was restarted by Liliana and Luis Avila (Canavesio 2005: 8ff).

What is important to note is that the Primitive Methodist Foreign Missionary Board was contracting Pentecostals to serve in Guatemala. The first Primitive Methodist missionaries to Guatemala were Carrie and Charles Truman Furman who were Pentecostals of Turtle Creek, Pennsylvania affiliation. Doctrinal differences between the Primitive Methodist Church, which is Evangelical, and the Pentecostal missionaries created disputes leading to a schism in 1934. The Bradleys, although Pentecostals, were Primitive Methodist missionaries at the time of the Primitive Methodist foreign mission board's dismissal of the Furmans resulting in the subsequent schism. At the time of the schism, in 1934, the Bradleys were serving in Chichicastenango, having taken over the work of Dr. Carlos Secord. The Bradleys, unlike Furman and Thomas Pullin, had good relations with the other missionaries (Dalhquist 1995: 118-120; Canavesio 2005: 6). Presbyterian missionary Paul Burgess translated with Bradley the Gospels of John and Matthew in K'ekchi'. This was beginning of a solid working relationship between the Primitive Methodists and the other missions in Guatemala that continues to the present. It was also the beginning of the Primitive Methodist's mission board's commitment, both in terms of translators and funds, for the translation of the Bible in K'iche. This work continues today with Primitive Methodist missionary William Vasey.

17 Thomas Pullin and Charles Truman Furman, of the United Free Gospel and Missionary Society, arrived the year the existing missions had come to a comity agreement. Their work in the territories of the established missions was successfully challenged until one of them, Charles Furman, became a missionary for the Primitive Methodists in Totonicapán. Charles Truman Furman and his wife, Carrie Smith Furman, of Pentecostal leanings in 1921 became Primitive Methodist missionaries in Guatemala. In 1932, the Furmans participated in a revival involving glossolalia which went against the official Primitive Methodist position. The Furmans resigned and in 1934 joined the Church of God (Cleveland, TN) taking with them two-thirds, or 14 churches, of the Primitive Methodist mission (Hays 1972: 19-20). A similar schism had taken place in Chile in 1908 (Case 2006: 130-131).

18 The National Baptist Association is an Evangelical church.

19 In 1933 President Ubíco invited US citizens to visit Guatemala. The Church of God wrote to Ubíco and received a formal invitation to evangelize in the country (Humphrey 1966: 64). 
(Rupert 1974: 58). The Moody Bible Institute (founded 1886 in Chicago, IL), the Altamont Bible and Missionary Institute (founded 1896 in Greenville, SC), and the Los Angeles Bible Institute (founded 1908 in Los Angeles, CA) were the beginning of a trend of establishing educational centers to train Sunday school teachers, missionaries, and preachers. By the 1930s, there were 50 such institutes in the US (Blodgett 1997: 39-40). The independent mission institutes evolved into Bible institutes providing preparatory courses for the lay as well as ordained ministers and evangelizing missionaries. The emphasis of the Bible institutes on lay evangelists was in sharp contrast to the ordained, college-educated missionaries of the mainline denominations.

Another feature of independent faith missions was lack of institutional financial support in the form of a salary that was characteristic of mainline Protestant missions. Financial support for Evangelicals and Pentecostals was to be freely given by motivated Christians and not to be solicited from secular sources such as groups of businessmen (Svelmoe 2008: 66-7). Pentecostal missionaries to Guatemala raised their own funds sometimes with several churches supporting them. This was the case with the work of the Church of Nazarene missionaries (funded by the Pentecostal Mission of Nashville and the Southern Pentecostal Union). ${ }^{20}$ The independent missions approach stressed premillennial beliefs, a focus on evangelizing, and lay missionaries with financial support from local churches and individuals Christians.

Like the work of the Presbyterian Church - US in the Republic of Korea, the missionary work in Guatemala embodied the "indigenous church" approach to missions by focusing on training native preachers and creating autonomous Guatemalan churches (Hudson 1976: 26; Winn 1970: 98). Indigenous approach in Guatemala emphasized two aspects of church growth. First, only indigenous lay pastors and leaders would have success in spreading the Gospel among their peoples. Second, the Scriptures, the Christian message of salvation, had to be contextualized, finding expression in the indigenous language (Dahlquist 1995: 26-43). The exception to the indigenous church approach was Edward Haymaker, a Presbyterian missionary, who remained in the minority in his Social Gospel orientation to missions (Bogenschild 1991: 8-9). The indigenous approach to missions was developed and promulgated by Rufus Anderson of the American Board of Commissioners for Foreign Missions and Henry Venn of the Christian Mission Society. ${ }^{21}$ Both men, one in the US and the other in the United Kingdom, argued that foreign missions should be "Self-supporting, self-governing, and self-propagating." ${ }^{22}$ The indigenous approach was further developed by John Livingston Nevius, a Presbyterian missionary to the People's Republic of China (PRC) (Johnson 2009: 411-412). The Nevius plan, adopted by Presbyterian Church - US missionaries in the Republic of Korea (Clark 1930) as well as Evangelical and Pentecostal missionaries in Guatemala, included the "three selfs" and itinerate evangelizing, Bible reading for all believers, and assistance to those in physical need (Kraft 2005: 43-44). This "three-selfs approach" to foreign missions continued well into the twentieth century although not without logistical conflicts arising as to when missionaries should turn over church property, funds, and leadership to national Christians. ${ }^{23}$

20 In 1915, the Pentecostal Mission and the Pentecostal Church of the Nazarene merged to form the Church of the Nazarene, which by the early 1950s had evolved into an Evangelical denomination.

21 Anderson 1869; Shenk 1983.

22 Venn quotation in Hodges 1953: 2-3.

23 The humanitarian response to the 1976 Guatemala earthquake in the form of funds and equipment from the United States brought to the fore existing tensions between indigenous leadership and missionaries. For example, the Primitive Methodist missionaries were confronted by the Guatemalan National Conference to decide the distribution of emergency funds from the International Missionary Board and to oversee reconstruction projects (Hays 1972: 61-63). 
From the beginning, many missionaries were not sufficiently funded by U.S. churches to support themselves. Funds were continually being raised in the United States from various sources and often for specific projects rather than general support. The lack of funding, in some instances, hastened the process of "indigenizing" the church. Second, the equalizing evangelical message of early Protestant missionaries_-saved" or "unsaved"-glossed over centuries of race-class distinctions of Spanish-Catholic origin. ${ }^{24}$ To Protestant missionaries the "unconverted" in Guatemala were on a par with the "unsaved" in the US. Yet, at the time US missionaries were entering Guatemala, President Justo Rufino Barrios eliminated the structural and political autonomy of the indigenous populations by abolishing communal property (ejidos) and re-introducing forced indigenous labor (mandamiento), an issue that would decisively turn Protestant opinion against the regime. Third, missionaries experienced high mortality and defection rates as well as extended or unplanned furloughs for health reasons. Malaria, yellow fever, amoebic dysentery, intestinal parasites, influenza were common as were undiagnosed conditions. ${ }^{25}$ Third, in terms of evangelizing, the missionaries primarily engaged in a strategy widely used in the US which was the printing and mass distribution of Scriptures, religious tracts and newspapers in Spanish. ${ }^{26}$ Distributing religious tracts in Spanish was not an effective means of communication particularly since the majority of Guatemalans spoke an indigenous language and only two of these languages, Kaqchikel and K'iche', had recently acquired written forms. The monopolistic Roman Catholic Church had forbidden anyone but priests to read Scripture and it was the priest who mediated access to the Bible.

Although only one mission, the Presbyterian Church - US, was a mainline denomination, all of the early missionaries shared the ecumenical ideal of converting the world to Christianity and the "near-inevitability of its attainment" (Hutchison 1987: 95). Differences on how this was to be achieved were not reconcilable but kept secondary for the sake of achieving their shared goal. In the US, the growth of denominations from the late 1800s onward, led to an ideological divergence with the "indigenous church" approach to missions heralded by the evangelical and Pentecostal churches. The essence of the indigenous church approach to missions was to preach (evangelize) and convert. The fundamentalist churches-Pentecostals and to some extent evangelicals - had remained true to the indigenous church approach of evangelization and doctrinal orthodoxy (through the inerrancy of the Bible).

The majority of missions in Guatemala from the beginning of Protestant presence in that country were evangelicals and Pentecostals. The ecumenical cooperation among the missionaries in Guatemala, first between the Presbyterian mission and the evangelical Central American Mission (CAM), and later including the California Yearly Friends Meeting (evangelical), the Primitive Methodists (evangelical), and the Nazarene (evangelicalPentecostal) resulted in two comity agreements (1903 and 1916). The practice of entering into comity agreements was fairly common worldwide among Protestant missions as they minimized competition by eliminating duplication and overlapping of work (Rouse and Neill 1968: 353-4).

24 The increasingly complex racial classification that developed toward the end of the colonial period (1600-1722) took on a surreal complexity in the post-colonial period (1722-1829). The economic situation in Guatemala deteriorated placing pressure on American-born of Spanish descent to seek entitlement to lands. Eventually, with the cause of independence $(1810$ - 1820s) the castas were lumped into a single category known as "ladino" (Hutcheson 2011; Mörner 1967).

25 Descriptions of the health conditions of the early missionaries are described in several sources, Bogenschild (1992: 127); Dahlquist (1995:56-58); Winn (1970:102).

26 In 1899, the first Presbyterian missionary to Guatemala, Albert Edward Bishop, distributed tracts at an annual fair in Guatemala City (Winn 1970: 94). His successor Haymaker engaged in the same activity (Bogenschild 1992: 9). This activity was carried out by missionaries of the various mission groups. Rather than focusing on whether the recipients could read the materials, the missionaries reported their satisfaction at having handed them out. 
As indigenous Christian converts proselytized among their linguistic group, they planted churches that were autonomous of missionary oversight. For the indigenous churches, the comity agreement held no authority and regional boundaries were irrelevant. The competition, resisted by the original Protestant missions, and which the Pentecostal churches fostered led to schisms. The Presbyterians, who had initially lost churches to the CAM were now losing churches to the Pentecostals. ${ }^{27}$ In 1918, the Presbyterians in the coffee growing town of Colomba encountered Seventh Day Adventists who established a church in the same locale with former Presbyterians (Bogenschild 1992: 235-6). CAM, a participant in the comity agreements, did not enforce the comity agreement among its missionaries as Herbert Toms, engaged in itinerate evangelizing in 1922 persuaded an entire Presbyterian congregation on the Finca Monte Grande to switch its affiliation to CAM (Bogenschild 1991: 29). One of the more illuminating schisms that typify the current Protestant religion market in Guatemala is the creation of the Guatemalan church Salas Evangelicas by a former Presbyterian, Carlos Kramer, who left the Presbyterian Church having been personally convinced by fundamentalists that baptism by immersion was Biblically correct (Bogenschild 1991: 30-1). ${ }^{28}$

Originally schisms among Protestant churches occurred over conflicts of doctrinal orthodoxy (Biblical interpretation) or one could say doctrinal confusions regarding such issues as baptism, marriage, and the role of women in the church. A third comity agreement (1935), reaffirming the earlier one of 1916 was done in a futile attempt to shut out Pentecostal competition. ${ }^{29}$ Whereas the disputes in the Korean Presbyterian church over doctrinal orthodoxy led to schisms on theological points, the schisms in the Guatemala increasingly were due to (i) the indigenization of mission churches, namely who would control the church and (ii) liturgical debates (forms of worship). The religion market in Guatemala from the inception of Protestantism was and continues to be characterized by a high level of schisms within evangelical, Pentecostal and neo-Pentecostal churches (McCleary forthcoming). These schisms are in large part due to succession issues as the model of father-son has been well-established. As a consequence, control of spiritual as well as economic resources is a family struggle and not a corporate one.

A long-held view is that Protestant missions contributed to increased human capital through mass education (Woodberry 2002, 2004, 2009; Nunn 2009). This argument holds true for societies with few converts to Protestantism (Woodberry and Shah 2004: 55). Becker and Woessmann (2009) found higher literacy rates in 19th Century Prussian Protestant areas than in Catholic ones. The implications of human capital in the form of literacy for economic development are multiple. None of these studies, however, examine how Protestants evangelized to indigenous cultures with their own languages and the implications of that evangelizing on human capital in the form of literacy. For example, Woodberry (2002) and Nunn (2009) do not discuss the transition from a non-literate society to a literate one in Africa taking into account the indigenous languages.

27 in 1096, the Presbyterian mission board expressed its frustration at the lack of success on the part of Presbyterian successes in Guatemala by comparing it with the Republic of Korea. "The whole body of communicants in Guatemala for nearly twenty years with the expenditure of from one to two hundred thousand dollars, does not equal the number which were baptized recently at one time by one of our Korean missionaries..." cited in Bogenschild (1991: 6, footnote 15).

28 Baptism for decades was a continually divisive sacramental issue. Missionaries abandoned their affiliations on this issue to join other missions (Svelmoe 2008: 131).

29 The two largest denominations in Guatemala by adherents-the Church of God Full Gospel and the Assemblies of God-have an elected executive board and annual meetings. Both churches are part of each denomination's world membership. These two denominations are the exception rather than the norm in Guatemala among Pentecostal churches. 
The Protestant missions in Guatemala initially did not have much success with their written translations of Bible scripture due to high illiteracy rates among the indigenous groups and the lack of printing presses. Even Spanish editions of the Bible were difficult to distribute due to the difficult terrain and the hostility of the indigenous communities (Table 2). Compared to Bible work in the Republic of Korea, Guatemala lacked willing indigenous colporteurs and did not engage indigenous women in this type of work.

Table 2: Scripture Circulation in the Republic of Korea and Guatemala, 1883-1913

\begin{tabular}{|c|c|c|c|c|c|c|c|c|c|c|c|}
\hline \multirow[b]{2}{*}{ Year } & \multicolumn{2}{|c|}{ Rep. of Korea } & \multirow[b]{2}{*}{$\begin{array}{l}\text { Total } \\
\text { Sales }\end{array}$} & \multirow[b]{2}{*}{$\begin{array}{c}\text { Total } \\
\text { Circulated }\end{array}$} & \multirow[b]{2}{*}{ Colporterus } & \multirow[b]{2}{*}{$\begin{array}{c}\text { Bible } \\
\text { Women }\end{array}$} & \multirow[b]{2}{*}{ Year } & \multirow[b]{2}{*}{$\begin{array}{c}\text { Guatemala } \\
\text { Bibles }\end{array}$} & \multicolumn{2}{|c|}{ (Spanish) } & \multirow[b]{2}{*}{ Colporterus } \\
\hline & Bibles & NT & & & & & & & NT & $\begin{array}{l}\text { Total } \\
\text { Sales }\end{array}$ & \\
\hline 1883 & & & & 1,000 & 1 & & 1883 & & & & \\
\hline 1895 & 32 & 393 & 1,253 & 1,253 & & & 1895 & & & & \\
\hline 1896 & & & 2,997 & 2,997 & 1 & 1 & 1896 & & & & \\
\hline 1897 & & & 4,678 & 6,335 & 8 & 4 & 1897 & & & & \\
\hline 1898 & & & 6,105 & 34,813 & 10 & & 1898 & & & & \\
\hline 1899 & & 2,047 & 17,505 & 46,121 & 14 & & 1899 & & & & \\
\hline 1900 & 88 & & 28,949 & 38,006 & 21 & 16 & 1900 & 1,358 & & 1,358 & \\
\hline 1901 & & & 12,612 & 16,824 & 40 & 15 & 1901 & 2,716 & & 2,716 & 2 \\
\hline 1902 & 158 & & 20,575 & 28,716 & 51 & 19 & 1902 & & & & \\
\hline 1903 & & & 16,707 & 28,853 & & 21 & 1903 & & & & \\
\hline 1904 & & & 35,593 & 52,003 & & 20 & 1904 & 5,465 & & 5,465 & 4 \\
\hline 1905 & & & 68,826 & 98,498 & 26 & 15 & 1905 & 6,948 & & 6,948 & \\
\hline 1906 & & & 63,829 & 127,269 & 26 & 16 & 1906 & & & & 2 \\
\hline 1907 & & & 57,894 & 151,230 & 64 & 18 & 1907 & & & & 1 \\
\hline 1908 & & & 60,581 & 162,687 & 68 & 17 & 1908 & 419 & & 419 & 2 children \\
\hline 1909 & & & 53,996 & 356,617 & 102 & 19 & 1909 & 4,363 & & 4,363 & 3 \\
\hline 1910 & & & 95,252 & 666,178 & & & 1910 & & & & \\
\hline 1911 & & & 115,893 & 263,296 & 146 & & 1911 & & & & \\
\hline 1912 & & & 141,445 & 183,845 & 157 & 33 & 1912 & 1,084 & & 1,084 & 1 \\
\hline 1913 & 2,623 & & 311,278 & 389,401 & 181 & 34 & 1913 & & & & \\
\hline
\end{tabular}

Source: British and Foreign Bible Society Annual Reports.

The approach the missionaries took starting in 1921 was to translate Scripture into indigenous languages so as to "indigenize" the written Gospel-to convert people and make a K'iche', Ke'kchi, Kaqchikel, Mam, Poqomchi' church. This approach fit with a literate society rather than cultures of "oral communicators" which characterized the indigenous populations of Guatemala. The intent of the missionaries was not mass education in the indigenous languages. The translations of Scripture were done to retain the meaning of the text but present it within the worldview of the Maya for evangelizing purposes. Realizing that the written word was not the most efficient medium for evangelizing, Protestant missionaries turned to recordings (fingerfonos, phonographs, cassettes, digital players) of hymns, Bible readings, and sermons as well as films dubbed in indigenous languages and later filmed in local contexts, led to conversion among the indigenous populations. Films, in particular, were useful in evangelizing as the visual medium attracted crowds of people and created trust (Weaver 2001: 193).

Another strategy of the Protestants was to evangelize at public gatherings, particularly the saints' feast days. A popular strategy shared by the Protestant churches was to set up a booth or pitch a tent at a Catholic patron saint's fiesta, play music (either live or on tape), hand out literature and preach over a portable bullhorn (Tracy 1961: 65-81; Teague 1966: 100-101; Central American Bulletin 403, 1967: 10-11; Vaughters 1968: 102; Schultz 1995: 90-91). Some showed films such as the "Life of Christ" and held children's classes under a tent (Hays 1972: 55). A saint's feast day is a fiesta del pueblo or public communal event where performances of 
dances take place and a fair occurs (Reina 1966:133; 142-162). ${ }^{30}$ Another evangelizing strategy was to travel from town to town showing films on a sheet hanging between two trees with a portable projector. Portable bullhorns were commonly used. Phonographs were used to play recording in Spanish and an indigenous language.

The missionaries developed an alphabet over time for each of the indigenous languages using the Latin alphabet. However, once having developed an indigenous alphabet, the missionaries were confronted with the daunting task of educating lay leaders who preached in their communities. As Woodberry (2004, 2009), Nunn (2009), and Bogenschild (1991) point out, Protestant missionaries set up schools that taught national elites the colonial language. Mass literacy was not the objective of these schools. In Guatemala, mission school curriculum was taught in Spanish to children of urban ladino, Spanish-speaking elites (Bogenschild 1991: 7-8). The first and two largest Protestant missions to Guatemala-Presbyterians and CAM - did not allocate resources to indigenous missions (Dahlquist 1995: 27). Both mission agencies had a long-standing policy of banning evangelization in indigenous languages.

The Panama Congress of 1916 reoriented US missions to evangelizing to indigenous peoples in their own language. In January of 1921, an ecumenical meeting of Protestant missionaries took place in the Indian highland town of Chichicastenango. The creation of the ecumenical agency-The Latin American Indian Mission-focused on translating the Gospel into native languages of Guatemala and thereby converting indigenous peoples to Christianity "in this generation" (Dahlquist 1995: 28; 43). The two major linguistic groups-Kaqchikel and K'iche'-have survived the Spanish conquest with written languages but with a Latin alphabet and Spanish Colonial orthography.

The Evangelical and Pentecostal missions in Guatemala, when compared to those in the Republic of Korea, did not invest significant resources in establishing educational facilities. Due to lack of data on primary and secondary schools, I compare university education in Guatemala and the Republic of Korea (Figure 1; Tables 3 and 4). The effect of mainline Protestant missions in the Republic of Korea on higher education was significant. By contrast, none of the original US missions to Guatemala established an institution of higher education. Missionaries in Guatemala placed their efforts in conversion and church-planting. The evangelical and Pentecostal missionaries lived among the indigenous populations, learned the indigenous languages and began translating books of the New Testament. The translations of Scripture were done to retain the meaning of the text but present the Christian message within the worldview of the Maya. To assist them in their efforts, the Protestant missions requested that the Wycliffe Bible Translators to work in Guatemala. In 1952, under the name Summer Institute of Linguistics (SIL), Wycliffe was officially invited into Guatemala by the government. The purpose of the translations that SIL would assist the missionaries with was for evangelical purposes not educational literacy.

30 The saints' cults were introduced by the Spaniards in 1540 as a means of converting the indigenous population to Roman Catholicism. Each indigenous community over time was assigned a saint and feast day (Remesal 1964: 246). Today, cities, towns, and indigenous communities (cantons and caserios) have a saint feast day that is celebrated over a short period of days with dancing, religious ritual, and social interaction at a fair. 
Figure 1: Upper Level Christian Schools in the Republic of Korea and Guatemala (numbers per million population)

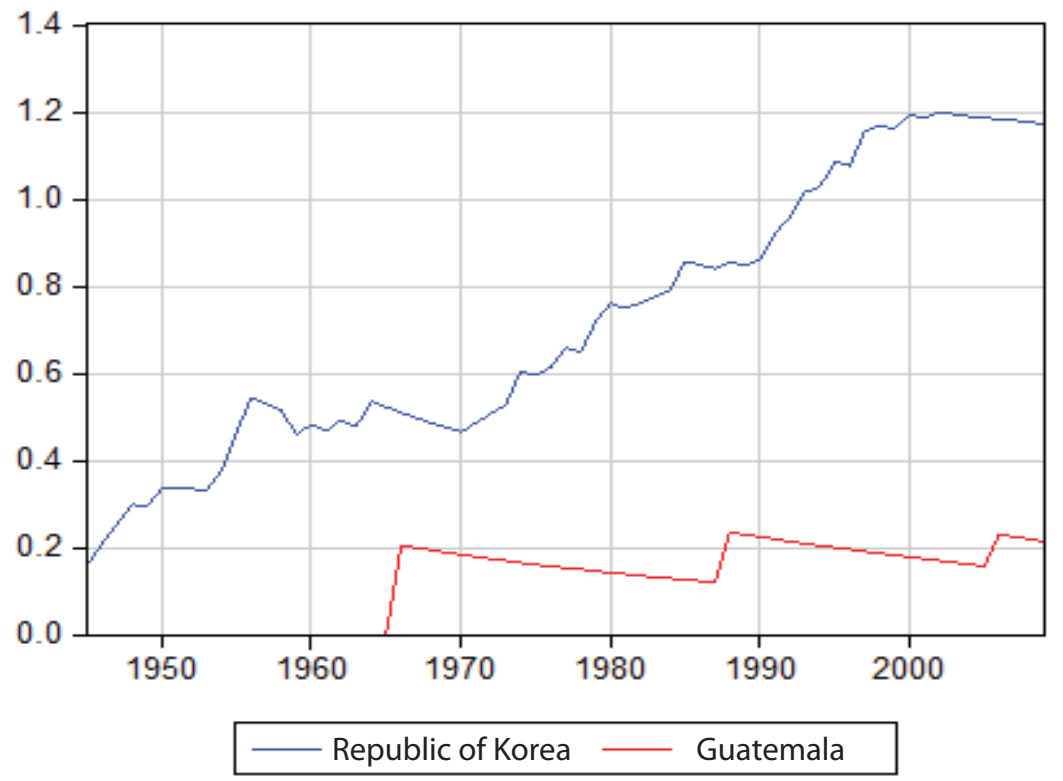

Table 3: Guatemala Universities

Christian Universities and Year of Founding

1961 - Universidad Rafael Landívar (Jesuit)

1966 - Universidad Mariano Gálvez (Evangelical)

1998 - Universidad Panamericana (EI Verbo, Charismatic-Evangelical)

2006 - Universidad San Pablo de Guatemala (El Shaddai, Pentecostal)

Table 3: Guatemala Higher Education Institutions (universities)

\begin{tabular}{|c|c|c|c|c|c|c|c|c|c|}
\hline \multirow[b]{2}{*}{$\begin{array}{l}\text { Schools } \\
\text { Classified }\end{array}$} & \multicolumn{3}{|c|}{ Number of Schools } & \multicolumn{3}{|c|}{ Number of Students } & \multicolumn{3}{|c|}{ Number of Professors } \\
\hline & Total & $\begin{array}{l}\text { National } \\
\text { and } \\
\text { Public }\end{array}$ & Private & Total & $\begin{array}{l}\text { National } \\
\text { and } \\
\text { Public }\end{array}$ & Private & Total & $\begin{array}{l}\text { Nationa } \\
\text { and } \\
\text { Public }\end{array}$ & Private \\
\hline University & 13 & 1 & 12 & 312,697 & 155,000 & 157,697 & & - & - \\
\hline $\begin{array}{l}\text { Education } \\
\text { Industrial }\end{array}$ & 0 & - & - & & & & & - & - \\
\hline University & 0 & - & - & & & & & - & - \\
\hline Total & 13 & 1 & 12 & 312,697 & 155,000 & 157,697 & & - & - \\
\hline
\end{tabular}

*Data for Air and Correspondence University are not included (2011)

Secular Universities and Year of Founding

1676 - Universidad de San Carlos de Guatemala, founded in 1676 as Roman Catholic and became the state, secular university in 1875.

1966 - Universidad del Valle de Guatemala

1971 - Universidad Francisco Marroquín

1995 - Universidad Rural

1997 - Universidad del Istmo

1999 - Universidad Mesoamericana

2000 - Universidad Galileo

2009 - Universidad InterNaciones

2010 - Universidad de Occidente 


\section{Table 4: Korean Universities}

Christian Universities and Year of Founding

1855 - Catholic University of Korea (Roman Catholic)

1885 - Yonsei University (Northern Presbyterians US, Methodist Episcopal Church-North, Methodist Episcopal-South, United Church of Canada)

1886 - Ewha Woman's University (Methodist Church-North and Methodist Church-South)

1897 - Soongsil University (Northern Presbyterian US)

1914 - Catholic University of Daegu (Roman Catholic)

1948 - Myongji University (Christian)

1954 - Keimyung University (Northern Presbyterian US)

1956 - Hannam University (Northern Presbyterian US)

1960 - Sogang University (Jesuit)

1962 - Syungkil University (Evangelical) Jesus Korea SungKyul Church (JKSC)

1964 - Jeonju University (Christian)

1970 - Hoseo University (Christian)

1995 - Handong Global University (Evangelical)

Table 4. Republic of Korea Higher Education Institutions (universities)

\begin{tabular}{|c|c|c|c|c|c|c|c|c|c|}
\hline \multirow{3}{*}{$\begin{array}{l}\text { Schools } \\
\text { Classified }\end{array}$} & \multicolumn{3}{|c|}{ Number of Schools } & \multicolumn{3}{|c|}{ Number of Students } & \multicolumn{3}{|c|}{ Number of Professors } \\
\hline & & $\begin{array}{l}\text { National } \\
\text { and }\end{array}$ & & & $\begin{array}{l}\text { National } \\
\text { and }\end{array}$ & & & $\begin{array}{l}\text { National } \\
\text { and }\end{array}$ & \\
\hline & Total & Public & Private & Total & Public & Private & Total & Public & Private \\
\hline University & 171 & 27 & 144 & $1,771,738$ & 387,299 & $1,384,439$ & 44,177 & 11,144 & 33,033 \\
\hline $\begin{array}{l}\text { Univ. of } \\
\text { Education }\end{array}$ & 11 & 11 & - & 23,259 & 23,259 & - & 721 & 721 & - \\
\hline $\begin{array}{l}\text { Industrial } \\
\text { University }\end{array}$ & 18 & 8 & 10 & 187,040 & 85,956 & 101,084 & 2,543 & 1,296 & 1,247 \\
\hline Total & 200 & 46 & 154 & $1,982,037$ & 496,514 & $1,485,523$ & 47,441 & 13,161 & 34,280 \\
\hline
\end{tabular}

*Data for Air and Correspondence University are not included

${ }^{*}$ Numbers of students and professors are based on the data as of April 1, 2002

The Republic of Korea has over 150 secular universities

In the 1970s, the Programa Linguística Francisco Marroquín (PLFM) was first established in Huehuetenango and then in Antigua. Terry Kaufman, an American linguistic, was a leader at this center. ${ }^{31}$ The United Nations adopted Kaufman's alphabet and approach but SIL retained its Latin alphabet continuing to rely on foreign missionaries. By fall 1987, the government of Guatemala adopted the PLFM alphabet for its new bilingual program in the public schools. (At this point, the SIL withdrew from working on the bilingual program). Literacy rates in Guatemala are only measured in Spanish (Figure 2). The bilingual program from its inception was viewed as a means on facilitating indigenous children's entry into the formal educational system with the goal of their learning Spanish. National measurements of literacy in the indigenous languages are not done and the success of the bilingual program can be assessed in terms of Spanish literacy rates, since that was the goal of the program. Figure 2 shows that literacy rates in Spanish are lower in departments with higher concentration of indigenous populations.

31 Warren (1998). 
Figure 2: Literacy Rates (Spanish) by Guatemala's Departments

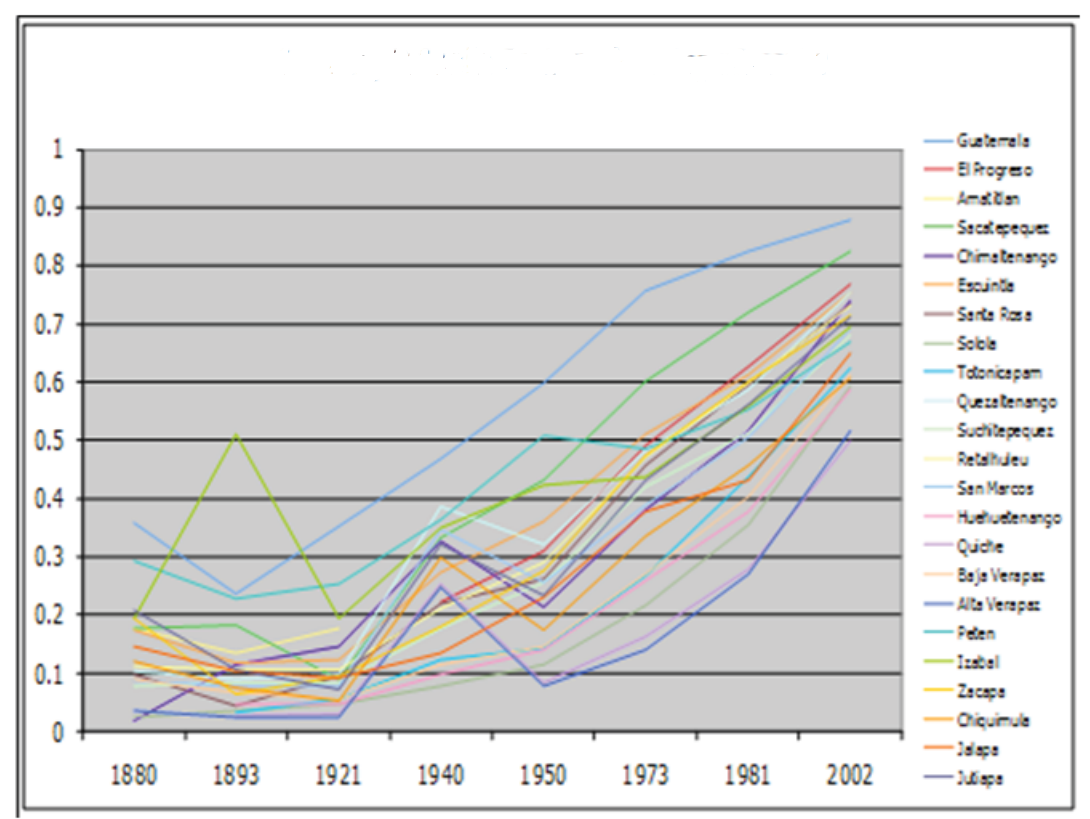

Although all three Protestant groups-mainline, Evangelical, and Pentecostal-have been establishing primary and secondary schools in Guatemala, the data are not collected by the national headquarters of the churches. The Government of Guatemala requires that schools be registered but the state does not keep a separate registry for religiously-affiliated schools. As a result is it currently impossible to provide a national statistical analysis of the presence of primary and secondary Protestant educational institutional in Guatemala.

\section{THE TRIUMPH OF THE SOCIAL GOSPEL IN THE REPUBLIC OF KOREA}

The mainline denominations, in the aftermath of the US civil war were formulating the Social Gospel (Eighmy 1969). Rather than passively awaiting the second coming of Christ, the denominations theologically shifted to an active Christian agency in changing the world by advocating against slavery, women's right to vote, and alcohol use. "The world was recognized as the only world in which human action could meaningfully occur, and, like it or not, with hope or with despair, people were called upon to act on the stage of history. And this meant-if one acted responsibly in a religiously plural setting-justifying one's actions not by revealed, otherworldly, or otherwise private criteria (even if one claimed such criteria as inspiration) but by the criteria of a secular, humanistic society" (Hammond 1983: 284). The leaders of the mainline denominations-Presbyterian Church (North and South) and the Methodist Church (North and South)-were college and seminary educated. ${ }^{32}$ Their Christian work was dedicated to improving the lives of peoples by bringing them education, medicine, and technological progress. Mainline Protestant denominations also professed political values of equality and democracy (Handy, 1971:101). This constellation of values: human improvement, equality, and

32 "Mainline mission boards, as compared to many minor, independent agencies that maintained less application requirements, recruited missionaries from middle-class families that formed the backbone of these white, Protestant denominations." For the most part, the mainline missionaries were college-educated and the men had seminary degree ( Ryu 2001: 95). 
technological progress were the central features of the Social Gospel missionaries brought to the Republic of Korea.

Beginning immediately upon Protestantism form entry into the Republic of Korea in 1884, four mainline denominations dominated the mission field-Presbyterian Church (north and south), Methodist Episcopal Church (north and south)—that engaged in medical and educational work. The Presbyterians, however, would quickly grow to be the largest Protestant denomination in the Republic of Korea (Shearer 1966: 190 and Table VII; Park 2003: 104). In April of 1885, the first Western medical hospital, Kwanghyewon (Global House of Benefits) was opened. Soon, medical and nursing schools were opened to train medical staff for the hospital. In 1886, the Methodist Ewha Girls School (today Ewha University) and the Pai Chai Hak Dang School for men were founded. ${ }^{33}$ By 1904, nineteen schools (Presbyterian and Methodist) were operating (Park 2003: 24, table 1.3). American teachers and doctors staffed the educational and medical facilities. For example, three students from the Union Theological Seminary of New York were recruited to come to the Republic of Korea to teach at the newly created Westernstyle Pai Chai Hak Dang men's school. The egalitarian principles of the Social Gospel were implemented in schools by giving women as well as men a similar education, regardless of socioeconomic conditions. Several Korean scholars have attributed to the mainline Protestant missions, particularly the Methodists, the country's modern curriculum and high literacy rates (Lee 1989: 90-1; Park 2000).

However, evangelizing polices of among the Presbyterians and between the Presbyterians and Methodists differed. The Presbyterian Church - US was split over its educational policy. Whereas the Presbyterian Church - US in Pyongyang educated primarily Christians and their children, the same church in Seoul implemented a policy of mass education regardless of religious affiliation (Shearer 1966: 201). The differences in policy were that the Presbyterian Church - US in Pyongyang had a large and growing Christian population. By contrast, Seoul's Christian community was small and formal education was viewed as a means of evangelizing to non-Christians and increasing adherents (Shearer 1966: 202-3). Regardless of this policy dispute within the Presbyterian Church -US (which became intense and public), the overall policy implemented in the Republic of Korea was the indigenization of the church, otherwise known as the Nevius plan. ${ }^{34}$ Because of the Nevius plan, converts were taught in Bible Institutes with an emphasis on trained pastors and leaders who could assume the responsibilities of a Korean church-in short (Clark 1986: 21-22). Unlike the Methodists who believed in a liberal arts education for the masses, the Presbyterians focused on creating indigenous leadership through the "the Bible training class system." The dispute among the Presbyterian Church - US missionaries and their mission board over the implementation of the Nevius plan resulted in a Presbyterian liberal arts college in Seoul not being established, giving the more conservative "Bible training" approach free reign (Chung 2001: 73). However, the Presbyterian Board of Foreign Missions, against the objections of its missionaries, accepted a large donation from Louis $H$. Severance, an American philanthropist, and in 1904 Kwanghyewon (Global House of Benefits) Hospital was rebuilt, modernized and renamed Severance Memorial Hospital (Shearer 1966: 204).

33 The first pupils of Ewha School were lower-class girls. For a history of Ewha University and the women missionaries who founded, directed, and taught at the school (Clark 2006: 177-181).

34 John Livingston Nevius, Presbyterian missionary to China, developed the mission policy from the work of Rufus Anderson of the American Board of Commissioners for Foreign Missions and Henry Venn of the Christian Mission Society (Clark, 1930). 
Medical work played a prominent role in the Presbyterian Church's missionary efforts in the Republic of Korea. A hospital was established in Pyongyang (1896) in conjunction with the Methodists, and in Chonju (1898), Taegu , and Pusan. The theological seminary in Seoul was operated in cooperation with the Methodists and represented only one example of denominational cooperation. Others included the Pierson Memorial Bible School, the Christian Literature Society and the Union Language School.

From the beginning, the Methodist Church (North and South) in the Republic of Korea focused its efforts on mass education for both genders. The Methodist Church, when compared to the Presbyterians, had more female missionaries who engaged in educational activities rather than evangelistic ones (Shearer 1966: 170-1). Korean women played a critical role in the conversion by confronting shamanism and reducing the authority shamans had over families. ${ }^{35}$ The conversion pattern in the Republic of Korea, as in Guatemala, was by family networks as villages consisted of families that were related by a common ancestor (Shearer 1966: 148-9). Once a parent or senior member of a family converted, the entire family would convert. Four months after the first Methodist missionary arrived in the Republic of Korea, a boys school was started (Paijai Boys High School).

By 1910, both Methodist and Presbyterian missions had established an estimated 796 schools (from primary to college) matriculating 41,000 students (Insoo Sohn cited in Lee 1989: 90). ${ }^{36}$

The mainline Protestant missionaries introduced the Korean language, "Hangul" into the curriculum of schools and hospitals (Lee 1989: 93). Unlike in Guatemala, where the majority of the population was indigenous speaking 25 different languages, the Korean population was homogenous and since 1443, the Republic of Korea had a well-developed written form of their language_-Hangul-although only a relatively small portion of the population could actually write at end of the nineteenth century. The Protestant missionaries intentionally adopted Hangul as the lingua franca of their schools and medical institutions. In 1890, the Korean Religious Tract Society was formed as well as the Trilingual Press. The amazing output of the presses in terms of Protestant tracts, portions of the Gospel, leaflets, pamphlets came to 1.8 million pages in one year (from June 1893 to July 1894) (Women's Foreign Mission Society, Presbyterian Church 1897: 161; Oak 2006: 75).

By contrast, at the end of the nineteenth century, Guatemala had at least 53 indigenous languages with no written alphabet. Only two indigenous languages (K'iche' and Kakchiquel) had been written in the Latin alphabet with colonial Spanish orthography. By 1894 the Gospel of Mark had been translated into K'iche' with only slightly over 1,000 printed (McCleary forthcoming). The difficult travel conditions but mainly the hostility, often violent, of the people's

35 Known as "Biblewomen," these Korean women traveled by foot in rural areas visiting villages where they sold Bibles in Korean and evangelized. Since ancestor worship in the home was prevalent in the Republic of Korea, reaching women was critical to breaking the hold of shamanism on families (British and Foreign Bible Society 1913: 363). "Biblewomen" were critical in reaching women and bringing them into the church (British and Foreign Bible Society 1898: 270). Their role expanded to include teaching women and girls how to read (British and Foreign Bible Society 1902: 291; 1909: 344; 1910: 353-5; Clark 2006: 170-1) and assisting female missionaries (both Methodist and Presbyterian), some of whom were doctors, in educating women about health care (Clark 2006: 170). Bible women attended courses at the Bible Institutes and received training in evangelizing and church leadership with many becoming deaconesses in their local churches (British and Foreign Bible Society 1913: 362; Clark 1986: 28-9; Clark 2006: 170-1). Important to note is that there was no equivalent in Protestant missionary and Bible work in Guatemala.

36 In 1927, the Presbyterian Church - US had 233 primary schools and the Methodist-North had 100 primary schools (Shearer 1966: 201). 
reaction to the sale of the Bible (the Roman Catholic Church outlawed the reading of the Bible by any person other than clergy) made evangelizing difficult (see Table 2). Whereas Koreans were receptive to Protestantism, in Guatemala religious intolerance had been taught by the Roman Catholic hierarchy for centuries.

Protestant missionaries in Guatemala quickly realized that the oral approach to evangelizing was more appropriate as no one could object to the presentation of the Gospel in that format. Furthermore, the majority of the Guatemalan population neither understood Spanish (the official language) nor wrote in their indigenous ones. Another possible interpretation is that the monopolistic nature of the Roman Catholic hierarchy did not want the indigenous populations to learn Spanish because they would then potentially be exposed to Protestantism (Lenning 1956: 6, footnote 4). Nor did the Roman Catholic hierarchy wish the indigenous populations to have access to the Gospel in their native tongue lest they become independent of the clergy.

Another aspect of the Social Gospel was the education of Korean leaders-Syngman Rhee, Philip Jaisohn (Chae Pil So), Chi-Ho Yun, and Kil-Jun Yu. These American-educated nationalist leaders, upon returning home from the US, began a nationalist movement against the Japanese occupation of the Republic of Korea (Park 2000: 511-515). The mainline Protestant focus on investment in human capital was based on the fundamental liberal values of equality, progress and human development (Lee 1989: 90; Park 2000: 516), ideals that the nationalist movement specifically incorporated into its agenda in form of universal education (Fisher 1928: 6).

The Presbyterians (north and south) were the largest Protestant mission in terms of number of personnel and activities (Shearer 1966). By 1905, The American Presbyterian mission (north) had 17,050 members and staff, American Presbyterian (south) 1,262, Australian Presbyterians 387, and Canadian Presbyterians 792. The Presbyterians had a total of 19,491 mission personnel and members in the Republic of Korea, out of a total of 30,088 Protestants including missionaries in the country. The trend of Presbyterians consisting of over half the foreign missionary presence in the Republic of Korea continued with the American Presbyterians (north) being the largest single mission (British and Foreign Bible Society reports 1903; 1913). In 1893 the four Presbyterian missions formed the Council for Mission of Presbyterian Churches and opened the theological seminary of Pyongyang (1901). By 1907, the four Presbyterian missions renamed their council the Union Presbyterian Church of Korea, with the eventual objective of establishing one Presbyterian Church in the Republic of Korea (formed in 1946). In 1892, the various Methodist and Presbyterian missions at work in the country reached a comity agreement so there should be no overlapping, duplication or waste (except for Seoul which was not included in the agreement). By this division the Methodists lost in numbers of adherents to the Presbyterians in the northwest region of the country which had the highest conversion rates in the Republic of Korea (Shearer 1966: 103-142; Park 2003: 105).

Toward the end of Japanese occupation as part of its continuing policy to undermine Neo-Confucian institutions and to shape Koreans into imperial subjects (kominka) the Japanese colonial administration required Shinto worship. ${ }^{37}$ Strong opposition to this obligatory policy was articulated by adherents of Taejonggyo, a new nationalistic religion founded in 1909 and Protestants. Finally, on 10 September 1938, the Presbyterian Church, at its 27th General Assembly meeting at the Pyongyang Westgate Church, acquiesced and approved shrine

37 Much has been written about the Shinto-shrine worship issue and the demise of Protestant missions to Korea. See, for example, Clark (1971) and Grayson (2001). 
observance. By 1941, most of the missionaries had left the Republic of Korea and the Presbyterian Church was reconstituted as the Chosun Presbyterian Church of Christ in Japan (1943). On 15 August 1945, Japan was defeated, the Republic of Korea was liberated, and on 17 August, those who had been imprisoned for their opposition to Shinto shrine observance were released. Two former imprisoned Protestant ministers, Joo Nam-Sun and Han Sang-Dong, founded the Korea Theological Seminary in Pusan to reintroduce doctrinal orthodoxy into the Presbyterian Church.

During the Japanese occupation of the Republic of Korea (1910-1945), Korean was outlawed in all its forms (written, spoken, and reading). At the end of Japanese occupation the first official measurement for illiteracy for Korean was estimated at $77 \%$ of the population (Meinecke 1958: 1). By 1957, 93.4\% of the population could read Korean (Meinecke 1958: 2). The spectacular increase in literacy rates was attributed to the emphasis on elementary school. Enrollment went from 1.6 million students in 1945 to over 3 million in $1957 .{ }^{38}$ One-fourth of the Korean population was enrolled in some type educational institution by 1957.

Figure 3: Literacy Rates in the Republic of Korea

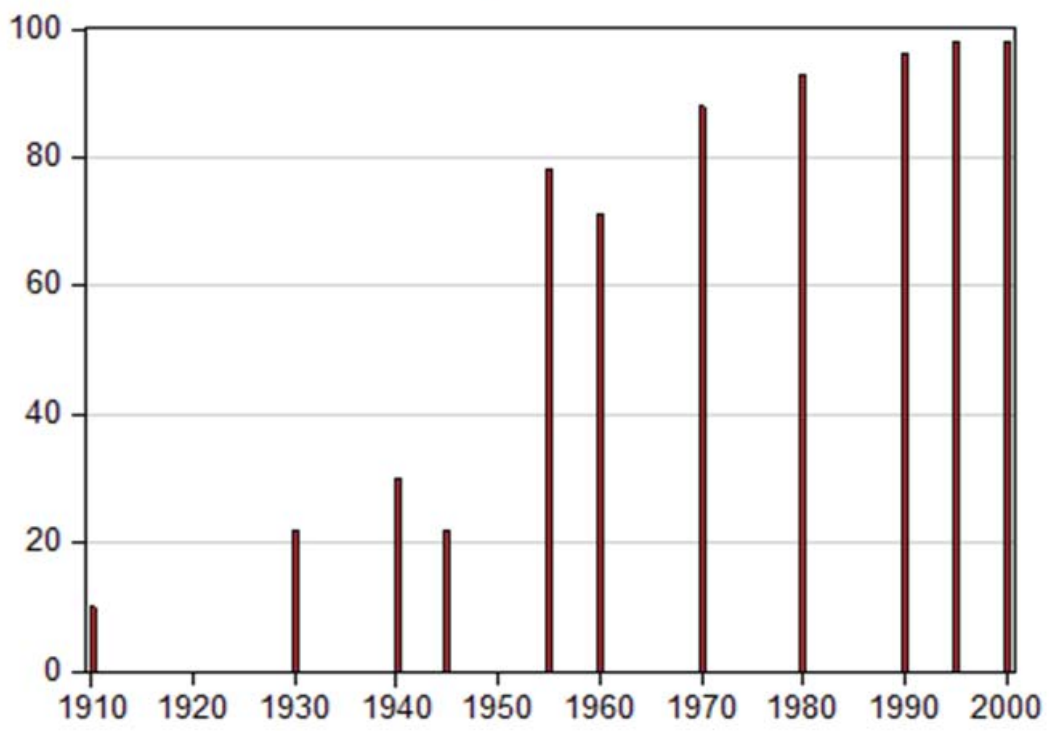

In 1981, the five largest Presbyterian churches joined to form the Council of Presbyterian Churches in [the Republic of] Korea. In 1995, three more churches joined the council. At the initiative of HapDong Presbyterian Church, an even larger association, mainly of conservative churches, came into existence in 1991. A merger of these two councils occurred in 1997 and it now represents the majority of Presbyterian churches in the Republic of Korea. This trend toward institutional homogeneity rather than continual schism reduces competition among institutions and increases cooperative use of resources. ${ }^{39}$ Cooperation characterized the work of

38 The first official census taken in 1949 recorded 20,188,641 Koreans.

39

DiMaggio and Powell (1983) contend that organizations become homogeneous in response to institutional changes resulting from the maturation of a field. A highly structured field provides a context in which individual efforts to deal rationally with uncertainty and contextual constraints lead to homogeneity in structure, culture, and 
the first Protestant missions to the Republic of Korea and such cooperation resulted in educational institutions functioning today. The main Protestant missions in the Republic of Korea and their effects on human capital are in sharp contrast to the fundamentalism of the Holiness movements and Pentecostals missions that entered Guatemala. Whereas the Presbyterian Church - US was the first legal mission to enter Guatemala, just as in the Republic of Korea, the Presbyterians in the country established medical facilities and schools some of which remain in existence today. By contrast, the Presbyterians in Guatemala were quickly outnumbered by the premillennialist interdenominational and independent missions.

The statement by the Foreign Missions Board of the Presbyterian Church - US in 1902 to one of its missionaries in Guatemala sums up the stark differences in the two mission fields:

The whole body of communicants in Guatemala for nearly twenty years with the expenditure of from $\$ 1,000$ to $\$ 2,000$, does not equal the number which were baptized recently at one time by one of our Korean missionaries. We do not deem it right to hold back missionaries from promising fields while we expend so much on a Mission that makes so little to show of results...." (cited in Bogenschild 1991: 6-7).

\section{CONCLUSIONS}

The Republic of Korea, unlike other Southeast Asian economies, accommodated mainline Protestantism, particularly after the Sino-Japanese War (Park 2003: Chapter 1). There are several endogenous reasons for this. The Republic of Korea was and remains one of the most homogeneous countries in the world. ${ }^{40}$ The homogeneity also means that the vernacular language, Korean, is not competing with various indigenous languages. The missionaries-both mainline and fundamentalist-promoted the Gospel in the vernacular, not because they were in favor of Korean nationalism, but to make the Bible more accessible for purposes of salvation. Education was for the most part universal and the adoption of Korean as the lingua franca facilitated the acceptance of mission institutions. The mainline Protestants in the Republic of Korea, to borrow a phrase from William Hutchison, "offered salvation through social, medical and educational agencies" (1987: 111). A caveat is needed in that even though the Presbyterian Church - US missionaries promoted the Nevius Plan of indigenous church growth their foreign mission board advocated the Social Gospel approach. The Nevius "indigenous church" approach was tempered not only by the policies of the foreign mission board but very much by the realities in the mission field. As a result the initial missionary focus on social service in the Republic of Korea and the institution-building that it required increased literacy rates and investment in types of human capital.

By contrast, the Guatemala government constitutionally permitted religious liberty allowing all types of Protestants into the country. The evangelizing strategy of the Evangelicals and Pentecostal missions were focused on conversion and church planting. Investment in formal education was minimal and complicated by the high illiteracy rates among the majority multi-lingual indigenous population. Mission resources were concentrated in translations of the Scriptures for conversion purposes only. The indigenous church approach to missions worked well for the Evangelical and Pentecostal missionaries as they focused on using oral and visual means of conversion, side-stepping formal literacy. The religion market in Guatemala, although

activity. DiMaggio and Powell define homogenization as the process by which organizations modify or take on characteristics that are increasingly compatible with environmental characteristics.

40

Since 1990, this has been changing with higher rates of intermarriage (Yang 2004). 
primarily Evangelical and Pentecostal became characterized by schisms and lack of doctrinal content which can be attributed to the low investment in formal education and low literacy rates. Even the Presbyterian Church, which traditionally invests in human capital, has had to lower its ministerial requirements from a high school degree to no minimum educational attainment in order to compete with the lay preachers produced by the Bible institutes of the Evangelicals and Pentecostals. In sum, the mission policies of the mainline Protestants in the Republic of Korea and that of the Evangelicals and Pentecostals in Guatemala adapted somewhat to pre-existing conditions in the two countries. Whereas the original Protestant missions in the Republic of Korea found a favorable matching of mission strategy with existing conditions (homogenous, monolingual society) so as to increase human capital, the Evangelicals and Pentecostal missions in Guatemala succeeded by not investing in traditional forms of human capital (literacy and health) . 


\section{REFERENCES}

American Bible Society. 1819. Annual Report. New York: American Bible Society. 1923. Annual Report. New York: American Bible Society.

Anderson, Rufus. 1869. Foreign Missions, Their Relations and Claims. New York: Scribner.

Becker, Sascha, and Ludger Woessmann. 2009. Was Weber Wrong? A Human Capital Theory of Protestant Economic History. Quarterly Journal of Economics 124 (2): 531-596.

Blodgett, Jan. 1997. Protestant Evangelical Literary Culture and Contemporary Society. Westport, CT: Greenwood Press.

Bogenschild, Thomas Edward. 1991. The Roots of Fundamentalism in Western Guatemala, 1900-1944. Paper presented at the Latin American Studies Association Meeting, Crystal City, Virginia 4 April.

1992. The Roots of Fundamentalism in Liberal Guatemala: Missionary Ideologies and Local Response, 1882-1944. Doctoral Dissertation, the University of California at Berkeley.

British and Foreign Bible Society. 1903. London: Bible House.

1914. London: Bible House.

Canavesio, June. 2005. International Pentecostal Holiness Church, Guatemalan History for Simultaneous Principle, International Pentecostal Holiness Church Archives and Research Center, Oklahoma City, OK. Unpublished manuscript.

Case, Jay R. 2006. And Ever the Twain Shall Meet: The Holiness Missionary Movement and The Birth of World Pentecostalism, 1870-1920. Religion and American Culture: A Journal of Interpretation 16, 2 (Summer): 125-160.

Chung, David. 2001. Syncretism: The Religious Context of Christian Beginnings in [the Republic of] Korea. Edited by Kang-nam Oh. Albany: State University of New York.

Clark, Allen D. 1971. A History of the Church in [the Republic of] Korea. Seoul: Christian Literature Society of Korea.

Clark, Charles A. 1930. The Korea Church and the Nevius Methods. New York: Fleming H. Revell Company.

Clark, Donald N. 1986. Christianity in Modern [Republic of] Korea. Lanham, MD: University Press of America.

2006. Mothers, Daughters, Biblewomen, and Sisters: An Account of "Women's Work in the [Republic of] Korea Mission Field. In Robert E. Buswell, Jr. and Timothy S. Lee, eds. Christianity in Korea. Honolulu: University of Hawai'i Press, pages 167-194. 
Dahlquist, Anna Marie. 1995. Trailblazers for Translators. Pasadena, CA: William Carey Library.

Di Maggio, Paul J. and Walter W. Powell. 1983. The Iron Cage Revisited: Institutional Isomorphism and Collective Rationality in Organizational Fields. American Sociological Review 48 (April): 147-160.

Eighmy, John Lee. 1969. "Religious Liberalism in the South during the Progressive Era." Church History, 38, 3 (Sept.): 359-372.

Fisher, James Earnest. 1928. Democracy and Mission Education in [the Republic of] Korea. New York: Teachers College, Columbia University.

Grayson, James H. 2001. "The Shintō Shrine Conflict and Protestant Martyrs in [the Republic of] Korea, 1938-1945. Missiology: An International Review 29 (3): 287-305.

Gribbin, William. 1975. A Matter of Faith: North America's Religion and South America's Independence. The Americas 312, 4 (April): 470-487.

Hammond, Phillip E. 1983. In Search of a Protestant Twentieth Century: American Religion and Power Since 1900. Review of Religious Research 24, 4. Voluntary Action and Religion: A Symposium (June): 281-294.

Handy, Robert T. 1971. A Christian America: Protestant Hopes and Historical Realities. New York: Oxford University Press.

Hays, Margaret N. 1972. An Outline History of Fifty Years, 1922-1972. Chichicastenango, Guatemala: Primitive Methodist International Mission Board.

Hodges, Melvin. 1953. The Indigenous Church. Springfield, MO: Gospel Publishing House.

Hudson, James. 1976. Guatemala: 60 Years. Kansas City, MO: Nazarene Publishing House.

Humphrey, Peggy. 1966. J. H. Ingram: Missionary Dean (Church of God World Missions). Cleveland, TN: Pathway Press.

Hutcheson, Maury. 2011. K'iche' Mayan Authorship in the Era of Liberal Reforms: A Social History of the Baile de los Mexicanos. Unpublished manuscript.

Hutchison, William R. 1987. Errand to the World: American Protestant Thought and Foreign Missions. Chicago: The University of Chicago Press.

Johnson, C. Neal. 2009. Business as Mission: A Comprehensive Guide to Theory and Practice. Downers Grove, IL: InterVarsity Press.

Kraft, Charles H. 2005. Appropriate Christianity. Pasadena, CA: William Carey Library.

Lee, Sungho. 1989. The Emergence of the Modern University in [the Republic of] Korea. Higher Education 18 (1): 87-116.

Lenning, John Tate. 1956. The Eighteenth-Century Enlightenment in the University de San Carlos de Guatemala. Ithaca, NY: Cornell University Press. 
Marsden, George M. 1980. Fundamentalism and American Culture: The Shaping of TwentiethCentury Evangelicalism, 1870-1925. New York: Oxford University Press.

1987. Evangelical and Fundamental Christianity. In Mircea Iliade, ed. The Encyclopedia of Religion. Volume 15: 190-197. New York: Collier Macmillan.

McCleary, Rachel M. Forthcoming. Protestantism and Human Capital in Guatemala. Unpublished manuscript.

Meinecke, Charlotte Drummond. 1958. Education in [the Republic of] Korea. Republic of Korea: Ministry of Education, October.

Mörner, Magnus. 1967. Race and Mixture in the History of Latin America. Boston: Little and Brown.

Nunn, Nathan. 2009. Christians in Colonial Africa. Unpublished manuscript.

Oak, Sung-Deuk. 2006. Chinese Protestant Literature and Early Korean Protestantism. In Robert E. Buswell, Jr. and Timothy S. Lee, eds. Christianity in [the Republic of] Korea. Honolulu: University of Hawai'i Press, pages 72-96.

Park, Chung-Shin. 2003. Protestantism and Politics in [the Republic of] Korea. Seattle: University of Washington Press.

Park, Yong-Shin. 2000. Protestant Christianity and its Place in a Changing [the Republic of] Korea. Social Compass 47(4): 507-524.

Reina, Ruben E. 1966. The Law of the Saints: A Pokoman Pueblo and Its Community Culture. Indianapolis: Bobbs-Merrill Company, Inc.

Remesal, Antonio. 1964. Historia General de las Indias de Occidentales y Particular de la Gobernación de Chiapa y Guatemala. Vol. 1. Madrid: Carlos Sáenz de Santa María.

Rouse, Ruth, and Stephen Charles Neill, eds. 1968. A History of the Ecumenical Movement, 1517-1948. Second edition with revised bibliography. Philadelphia: Westminster Press.

Ryu, Dae Young. 2001. Understanding Early American Missionaries in [the Republic of] Korea (1884-1910): Capitalist Middle-Class Values and the Weber Thesis. Archives de Sciences Sociales des Religions 46e Année, 113 (January-March): 93-117.

Schultze, Quentin J. 1992. Catholic v. Protestant: Mass-mediated Legitimation of Popular Evangelicalism in Guatemala. Public Relations Review 18 (3): 257-263.

Shearer, Roy E. 1966. Wildfire: Church Growth in [the Republic of] Korea. Grand Rapids, MI: William B. Eerdmans Publishing Company.

Shenk, Wilbert R. 1983. Henry Venn, Missionary Statesman. Maryknoll, NY: Orbis Books.

Steigenga, Timothy. 2001. The Politics of the Spirit: The Political Implications of Pentecostalized Religion in Costa Rica and Guatemala. Lanham, MD: Lexington Books. 
Strickland, William J. with H. Ray Dunning. 1998. J. O. McClurkan: His Life, His Theology, and Selections from His Writings. Nashville, TN: Trevecca Press.

Svelmoe, William Lawrence. 2008. A New Vision for Missions: William Cameron Townsend, the Wycliffe Bible Translators, and the Culture of Early Evangelical Faith Missions, 18961945. Tuscaloosa, AL: The University of Alabama Press.

Teague, Denzell. 1966. A History of the Church of God in Guatemala. Master'sThesis. Trinity Evangelical Divinity School.

Tracy, Olive G. 1961. We Have Seen the Sun. The Work of the Church of the Nazarene Among the Indian Tribes of Guatemala. Kansas City, MO: Nazarene Publishing House.

Vaughters, William C. 1968. Fruits of Progress: The Church of the Nazarene in Mexico and Central America. Missionary Study Book 1968-69. Kansas City, MO: Nazarene Publishing House.

Warren, Kay. 1998. Indigenous Movements and Their Critics: Pan-Maya Activism in Guatemala. Princeton, NJ: Princeton University Press.

Weaver, Andy and Carol. 2001. The CAB Family. Guatemala: Instituto Linguístico de Verano.

Winn, Wilkins B. 1970. Albert Edward Bishop and the Establishment of the Central American Mission in Guatemala, 1899-1922. In Eugene R. Huck and Edward H. Moseley, eds. Militarists, Merchants and Missionaries: United States Expansion in Middle America. Tuscaloosa, AL: University of Alabama Press: 93-106.

Woman's Foreign Mission Society of the Presbyterian Church. 1897. Historical Sketches of the Missions under the Care of the Board of Foreign Missions of the Presbyterian Church U.S.A. fourth edition. Philadelphia, PA: Woman's Foreign Mission Society of the Presbyterian Church.

Woodberry, Robert. 2002. The Shadow of Empire: Church State Relations, Colonial Policy and Democracy in Postcolonial Societies. Unpublished paper.

Woodberry, Robert. 2009. Weber through the Back Door: Protestant Competition, Elite Dispersion and the Global Spread of Democracy. Paper presented at National Bureau of Economic Research, Cambridge, MA. 15 October.

. 2011. "The Missionary Roots of Liberal Democracy." Conditionally accepted at the American Political Science Review. November.

Woodberry, Robert and Timothy Shah. 2004. "The Pioneering Protestants." Journal of Democracy, 15, 2 (April): 47-61.

Yang, Seung-ju. 2004. "Republic of Korean Government's Integration Policy for International Spouses." http://www.iom.int/jahia/webdav/site/myjahiasite/shared/shared/mainsite /microsites/IDM/workshops/Migrants_and_Host_Society_12130706 /seminar\%20docs/ROK-YangSeungju_7_July.pdf 


\section{Protestantism and Human Capital in Guatemala and the Republic of Korea}

Protestant missions from the United States entered the Republic of Korea and Guatemala at roughly the same time in the late 1900 s yet their impact on human capital has been divergent. In the Republic of Korea, mainline Protestant missions promoted the social outreach, building schools, churches, and medical facilities and promoting the use of Hangul. Meanwhile, in Guatemala, Evangelical and Pentecostal denominations focused their efforts on conversion, focusing on eschatological urgency. As a result, Protestant missions in the Republic of Korea built institutions that were conducive for further investment in human capital, but not in Guatemala. As a result, these diverging approaches to exporting Christianity have had different long-term impacts on the two societies.

\section{About the Asian Development Bank}

$A D B$ 's vision is an Asia and Pacific region free of poverty. Its mission is to help its developing member countries reduce poverty and improve the quality of life of their people. Despite the region's many successes, it remains home to two-thirds of the world's poor: 1.7 billion people who live on less than $\$ 2$ a day, with 828 million struggling on less than $\$ 1.25$ a day. ADB is committed to reducing poverty through inclusive economic growth, environmentally sustainable growth, and regional integration.

Based in Manila, ADB is owned by 67 members, including 48 from the region. Its main instruments for helping its developing member countries are policy dialogue, loans, equity investments, guarantees, grants, and technical assistance.

Asian Development Bank

6 ADB Avenue, Mandaluyong City

1550 Metro Manila, Philippines

www.adb.org/economics 